\title{
A CIDADE DO DEVIR NA UTOPIA DE THOMAS MORUS*
}

\author{
JORGE LUIZ BARBOSA \\ Universidade Federal Fluminense
}

\begin{abstract}
Uma coisa é certa: a utopia - e isto desde Thomas Morus - não é um futuro, e sim um outro lugar. Na realidade, não trata de imaginar, em um processo prospectivo, um novo mundo, mas localizá-lo, aqui e agora, no centro mesmo do antigo mundo.
\end{abstract}

Thierry Paquot

\section{A Utopia como ficção do espaço social}

Apesar dos cinco séculos da publicação da obra patronímica de Thomas Morus A Utopia - não se esgotaram as suas reverberações filosóficas e implicações políticas. Muitas dessas repercussões advêm, evidentemente, das explorações múltiplas da forma-conteúdo da própria obra. Outras, embora inspiradas no argumento temático de Morus, passaram a despertar novas angulações e tratamentos do eixo descritivo e interpretativo original. Assim, retomar o debate a respeito das Utopias sugere localizar como ponto de partida não só a obra de Morus stricto sensu, mas incluir, necessariamente, as suas diferentes apropriações que conduziram a re-significações da expressão Utopia e, conseqüentemente, de seu significado ético e estético. Nos propomos, portanto, nesse momento de nossa investigação, construir um mapa que, tendo como eixo do debate a obra de Morus, inclua as Utopias como passagem e fio condutor de leitura da cidade como Obra de Arte.

\footnotetext{
* Este texto é o capítulo II da tese de doutorado defendida na USP em 2002, de título As Passagens Crepuslares da Fiç̧ão Científica: a elegia da utopias urbanas do modernismo.
} 
Começaremos nossa reflexão pela própria expressão Utopia, um neologismo latino que deriva de duas palavras do léxico grego: ouk, cujo significado é uma negação aparecendo normalmente reduzida para ou diante de consoantes - e abreviada em $u$ para comportar a imagem verbal não; e topos (lugar), acrescida do sufixo ia, indicativo de um estado ou condição derivada de um lugar. Temos aí a construção da expressão Utopia, que aparece pela primeira vez na Carta a Pedro Gilles (Secretário da cidade de Antuérpia) escrita por Morus em outubro de 1516 e que é incluída, como prefácio, na primeira edição do seu mais conhecido livro. As traduções do neologismo Utopia são diversas: não-lugar, nenhum lugar, algures, nenhures, lugar algum. Estas abrigam diferentes representações do sentido da expressão Utopia, provocando, inclusive, aporias em termos de sua definição. Destacaremos, em nossa análise, três caminhos possíveis para seu entendimento: substantivo, gênero e ficção.

Como substantivo comum, a expressão Utopia é tomada como uma sinonímia do distante inalcançável, o sonho irrealizável, fantasia, quimera, insensatez. Sob o domínio do senso comum e ao abrigo de um sentido pejorativo, a Utopia como substantivo reúne a força ideológica de desqualificação de idéias, projetos e invenções lançadas a um futuro considerado pouco ou nada verossímil. Com esse tratamento genérico e vulgar, a Utopia torna-se apenas uma licença provisória para um sonho humano irrealizável, e portanto condenado inexoravelmente ao fracasso. Como exemplo, podemos lembrar a crítica ideológica de matriz conșervadora (e até mesmo liberal) em relação ao socialismo (e ao comunismo) como projeto político e social. Nesse caso, a Utopia e o socialismo estão lançados no limbo da história.

Uma outra possibilidade de tratamento da Utopia é considerá-la como um gênero literário que possui traços próprios de criação discursiva. Seu plano estilístico tem obviamente como referência maior o trabalho de Thomas Morus, delineando um campo de representações cuja característica mais imediata é voltar a imaginação para o futuro como uma negação do presente. Lacroix (A Utopia - Um convite à filosofia) afirma que Utopia como gênero exige, sobretudo, que as suas representações apareçam com certo grau de convencionalidade, tornando sua existência uma possibilidade:

Daí nenhuma fantasmagoria é possível; não se trata de imaginar monstros ou outros prodígios no delírio de uma produção sem regra de verossimilhança, expansiva, transbordante, excessiva, de uma proliferação indeterminada. A Quimera, figura de alhures, é certamente utopista pelo fato de que através dela se percebe o processo de destruição/reconstrução que leva um mundo real a um outro mundo (suposto): o ser fantástico mostra que o real atual é ordem relativa que uma desordem poderia transformar em outra ordem. Mas a Utopia não é uma Quimera: ela é (imaginariamente) o tempo do processo, ou seja, uma nova realidade cuja essência aparece diretamente na existência. (LACROIX, 1996: p. 65)

Na sua Utopia, Morus insiste em dar o máximo de veracidade à personagem Rafael Hitlodeu, nutrindo-o com os relatos de viajantes da época, de modo especial 
os de Américo Vespúcio, do qual teria sido um companheiro de navegações. A precisão de detalhes que o texto do jurista inglês evoca na descrição da Ilha é, sem dúvida, um outro ponto importante do esforço de dotar a narrativa de verossimilhança. Rafael relembra situações captadas ao vivo e, através delas, relata detalhes de sua experiência. Portanto, trata-se de uma construção discursiva apoiada em imagens que reclamam a existência indubitável de uma memória, a exemplo do seguinte diálogo entre o autor e o viajante-personagem:

- Pois então, disse eu a Rafael, fazei-nos a descrição dessa ilha maravilhosa. Não suprimas nenhum detalhe, suplico-vos. Descrevei-nos os campos, os rios, os homens, os costumes, as instituições, as leis, tudo o que pensais que desejamos saber, e, acreditai-me, esse desejo abarca tudo o que ignoramos.

- Com muito gosto, respondeu Rafael, pois todos essas coisas estão sempre presentes à memória.( MORUS, 1997: p.52)

O estilo envolvente dos diálogos do Livro I e das descrições pormenorizadas da Ilha no Livro II são demonstrações do empenho na construção da relação essênciaexistência no plano da representação utópica. Duas Ilhas se encontram no plano discursivo e representacional: a Inglaterra e a Utopia. Ambas constituem referências através das quais Morus traça um vasto mapeamento das questões políticas, econômicas e religiosas de sua época. Nesse sentido, tomar a obra de Morus como referência fundante da expressão Utopia é reconhecer, obrigatoriamente, o distanciamento do imaginário utópico das representações do fantástico que alimentaram (e alimentam) nossa imaginação com países idílicos, criaturas bizarras e viagens escatológicas:

\section{(...) Nós nada lhe perguntamos sobre esses monstros famosos que já perderam o mérito de} novidade: Cila, Selenos, Lestrigões, comedores de gente, e outras harpias de mesma espécie que existem em toda parte. $O$ que é raro, é uma sociedade sã e sabiamente organizada. (MORUS, idem, p.23)

A Utopia não é uma fantasia inconseqüente ou extravagância, mas imaginação concreta, como relembra Teixeira Coelho ( $O$ que é Utopia), cujo lastro de plausibilidade é dado pela realidade da própria antecipação visada. A Utopia como gênero é um modo de manifestação da razão e não somente uma mera insatisfação com o mundo real que corresponderia à criação de situações ideais:

(...) Rafael notou entre esses povos instituições tão ruins como as nossas, mas observou também um grande número de leis capazes de esclarecer, de regenerar as cidades, nações, e reinos da velha Europa. (MORUS, ibidem, p.23)

Desse modo também podemos traçar uma linha divisória da Utopia em relação à narrativa mítica. No mito, o contingente e o imponderável tecem o envolvimento das 
representações com o mundo das experiências concretas, estabelecendo linhas de força de leitura e apropriação cultural do significado do real na história social. $\mathrm{O}$ tempo e o espaço são postos em suspensão como protoformas para a rememoração de um acontecimento pedagógico e/ou performático de um determinado grupo, comunidade ou sociedade, valendo-se, inclusive, da abolição de regras formalísticas para uma livre associação e agenciamento de unidades episódicas. A Utopia emerge como uma narrativa de modelos exemplares tal como os mitos, porém seu deslocamento espaço-temporal se realiza como uma composição analítica, cujo objetivo maior é elucidar o momento vivido por uma dada sociedade e, ao mesmo tempo, estabelecer um programa ou projeto perspectivo de mudança.

É desse modo que R. Ruyer (L'Utopie et les utopies) nos fala de uma intenção da Utopia, pois considera que o fio condutor dos utopistas é um modo/método racional, muito próximo dos procedimentos ordinários de invenção científica. Para ele, a Utopia é um jogo sério, onde o utopista não perde o senso das possibilidades ao trocar de mundo. Conclui-se, então, que para Ruyer a Utopia não vale pelas suas intenções, mas pela sua capacidade de dotar de legibilidade e inteligibilidade as suas perguntas e respostas em relação ao mundo. A Utopia aparece, então, como um gênero discursivo de potência cognitiva.

Porém, seria exclusivamente a noção de entendimento que estaria em causa na imaginação utópica? E a perspectiva de mudança de que as Utopias são sempre portadoras? Ruyer não foge ao debate ao afirmar que o sonho especulativo das Utopias é um desejo de poder do seu criador. A dominação estaria na base da imaginação/especulação utópica como uma compensação para a impotência congênita da razão diante do mundo, tornando-as mais nocivas do que úteis. Percebe-se, então, que o elogio às Utopias se torna uma refutação erudita à Utopia, inscrevendo o gênero no campo das doutrinas e das ideologias. É Chesterton quem enfatiza tal oclusão da Utopia:

(..) a Utopia mais democrática é sempre, na verdade, o quadro de uma tirania e o sonho de um tirano, que vem a ser o próprio utopista dando-se a satisfação de arrumar o mundo à sua feição ( CHESTERTON, Apud LACROIX, 1996: p.12).

Essa composição positiva-negativa das Utopias assenta-se no terreno da crítica liberal-burguesa aos discursos contrários aos princípios regedores da ordem estabelecida, sobretudo os de vertente socialista e comunista. Como resultado temos a difusão de uma crítica ideológica (portanto, superficial) que enquadra, com seu sectarismo, as Utopias no campo do totalitarismo político.

Mannhein (Utopia e Ideologia) já havia refutado essa inscrição determinista das Utopias no campo das ideologias e doutrinas, afirmando que as Utopias representavam aspirações e imagens-de-desejo que se orientavam pela oposição com a ordem estabelecida e pelo exercício de uma função subversiva do status quo. Enquanto as ideologias seriam eminentemente conservadoras e empenhadas na reprodução das relações sociais, as Utopias seriam apontamentos para as mudanças em relação ao 
presente. Todavia, Utopias e ideologias guardavam, para aquele filósofo alemão, uma forma de falsa consciência, isto é, representações que transcendem a realidade e obscurecem - ou concorrem com - as representações compatíveis com o ser social real (Seinskongruenten).

L. Marin (Utopies: Les Jeux d'Espace), apoiado numa profunda leitura crítica das contribuições de Morus, traça um plano de distinção entre a escritura utópica e a ideologia. Para ele:

A Utopia é uma crítica da ideologia dominante, à medida que ela é uma reconstrução da sociedade presente por deslocamento e uma projeção de suas estruturas no discurso de ficção. Ela é, portanto, diferente do discurso filosófico da ideologia que é a expressão totalizadora da realidade dada e sua justificação ideal ( MARIN, 1975: p.249).

\section{E, acrescenta:}

(...) a Utopia, pela representação figurativa que a constitui essencialmente, subverte o discurso ideológico da realidade histórica; discurso que exprime e imobiliza no sistema fechado de idéias que visam dar uma representação justificada e legitimada. A Utopia como figura inscrita no discurso moral coloca em jogo o discurso ideológico, o sistema de suas representações no duplo sentido de um questionamento crítico implícito e de uma posição de distância, de uma reflexão interna que revela a pré-suposição das certezas de sua evidência ( MARIN, ibidem, p. 249/250).

O ser da Utopia é revelado na sua oposição às ideologias dominantes, mas isto não significa dizer que o discurso utópico é a-histórico, pois sua existência é condicionada socialmente através de valores, juízos, tradições e representações culturais. A Utopia não transcende a realidade no seu modo de existência, como argumenta Manhein. Ao contrário, faz do real-concreto-presente a sua argila primordial para o exercício de negação propositiva das condições históricas. A Utopia não faz parte da história geral das ideologias nem é uma ideologia na sua manifestação particular, pois seu corpus crítico implica o trabalho do negativo face aos sistemas de representação envolvidos na reprodução de uma ordem dominante e excludente de relações sociais. Contudo, não advogamos, tal como L. Marin, uma neutralidade discursiva da Utopia e das Utopias em geral, frente aos condicionamentos políticos e culturais, mas sim uma autonomia (sempre relativa!) diante dos pressupostos ideológicos hegemônicos.

O empenho balizador do discurso utópico é contrapor-se às limitações impostas ao imaginário, responsáveis pela banalização do real e pela vulgarização da vida social. É assim que Morus constrói a narrativa utópica como um recurso metonímico ficcional, cujo objetivo é estabelecer uma relação de oposição e de rompimento com a continuidade do mundo como ele é, implicando, como assinala J. Szachi (As Utopias), uma posição definida do ideal em relação à realidade. 
A proposta de trazer o ideal para a tessitura de apontamentos críticos do presente, traça um limite tênue entre a Utopia como ficção e os mais diferentes idealismos, tal como advoga J. Rudzki:

A Utopia como forma ideal de relações sociais é elemento o mais generalizado no mundo espiritual. Faz parte de todas as crenças religiosas, teorias morais e legais, sistemas de educação, criações poéticas, em uma palavra, de todo o conhecimento e obra que visa oferecer modelos para a vida humana. É impossível imaginar qualquer época, nação ou mesmo indivíduo que não tenha sonhado com o céu na terra, que não tenha sido mais ou menos utópico. Onde quer que existam - elas existem em toda parte - miséria, injustiça e dor, haverá também especulações sobre como erradicar as causas do mal. Na imensa escala que se estende por toda a história da cultura, desde as fantasias do nômade selvagem até as reflexões do filósofo moderno, encontra-se uma infinidade de versões da Utopia (RUDZKI, Apud SZACHI, p. 8).

Apesar de toda a sua generosidade com as Utopias, Rudzki rouba-lhes a historicidade para localizá-las no veio comum do idealismo. É evidente que as Utopias se nutrem de ideais, porém estes são transpostos para o sentido ético assumido no discurso utópico. O tema da Utopia é a ética nas relações humanas, pois são humanos os problemas e suas possibilidades de superação. Na Utopia, o algures radical enseja a virtude como a busca do prazer (bom e honesto) e a razão como a comunhão natural entre os homens capaz de proporcionar, a todos, os mesmos benefícios. Nas edições de 1518, Morus chama a sua Ilha de "EUtopia". As Utopias não se localizam em qualquer lugar ou em lugar algum, mas no país da Felicidade. Não pode haver riqueza maior, afirma Rafael, que viver o espírito completamente livre de toda preocupação e a alma repleta de alegria e felicidade. A Utopia, como ficção, se define na qualidade de um projeto de espaço social.

Todavia, não é por comportar um ideal de mudança que a Utopia se apresenta em todos os sistemas doutrinários, filosóficos e religiosos. O epicurismo, presente na Utopia, não significa uma busca do passado clássico perdido ou a vida monástica em uma clausura típica dos monastérios medievais. A Utopia não é uma mera reprodução de pressupostos ético-filosóficos ou secularização de doutrinas. A obra de Morus representa um sistema próprio de argumentação reflexiva das relações humanas no mundo que, indiscutivelmente, toma assento em concepções filosóficas e doutrinárias para refazê-las à luz de condições outras da existência humana. A escritura utópica pode até nutrir ou ser nutrida de elementos culturais outros, porém, seu construto apela para as virtualidades do mundo como vocação de um ser ideal de uma existência possível. Isto não significa incluí-la entre os milenarismos e movimentos messiânicos, ou mesmo localizá-la no conjunto de aportes filosóficos metafísicos, embora a redenção humana e a superação ontológica façam parte de sua nervura discursiva.

As Utopias reivindicam um espaço-tempo humano, com um motivo e uma imaginação humana; o paraíso utópico é sempre terrestre. Assim, podemos assinalar que 
as Cidades de Deus e a do Sol (de Santo Agostinho e de Tommasio Campanella, respectivamente), não se apresentam como obras precursoras ou derivativas da Utopia, pois encerram do ponto de vista teórico e prático uma negação da Utopia. São, na verdade, obras antiutópicas, apesar de toda ou qualquer simpatia e importância cognitiva que trazem para o entendimento da sociedade ocidental, pois deslocam para um devir celeste a regeneração da humanidade. Podemos afirmar o mesmo a respeito dos quiliasmas e/ou milenarismos, pois esses repousam suas projeções de futuro na realização terrestre de reinos celestes. É preciso refazer distinções conceituais entre o que é a escritura ficcional utópica e o que se convencionou indevidamente e genericamente como Utopias.

Nas obras de K. Marx e F. Engels - Manuscritos Econômicos e Filosóficos, Ideologia Alemã, A Sagrada Familia, A Miséria da Filosofia, Guerra Civil em França, $O$ Manifesto Comunista - encontramos uma forte (e irônica) rejeição à "tarefa Utopiana" típica de quem se entrega ao exercício de construções ideais de antecipação do futuro. Marx chamava de utópicos os autores e posicionamentos políticos que anunciavam a chegada de um "novo" mundo, mas que eram incapazes de superar o "velho". A condenação crítica das Utopias era endereçada especialmente às proposições de futuro que, para o autor d' $O$ Capital, representavam formulações incapazes de ultrapassar os horizontes burgueses de interpretação das lutas sociais e da economia política e, por isso, apenas afirmavam a permanência do presente quando descreviam um futuro idílico.

Segundo K. Marx, tais antecipações do devir estavam marcadas por concepções idealistas e doutrinárias. Nas idealistas elaboravam-se as antecipações cujos conteúdos excediam aos meios de sua realização, enquanto nas doutrinárias a invenção das formas substituía as próprias condições de emancipação. Apesar de toda a oposição, Marx e Engels consideravam, no Manifesto Comunista, as antecipações do futuro dos "socialistas utópicos", como as primeiras aparições de consciência do início do movimento comunista:

Esta descrição imaginária da sociedade futura, em uma época onde o proletariado é pouco desenvolvido e não observa sua própria situação, a não ser na imaginação, corresponde às primeiras aspirações intuitivas do proletariado em uma transformação completa da sociedade (MARX, K.e ENGELS, 1985: p. 51).

Embora reconheçam os elementos críticos nas visões do futuro e seu papel valoroso para o esclarecimento cultural da classe operária, através das suas propostas de sociedades futuras, tais como a supressão da distinção entre a cidade e o campo, abolição da família e do lucro privado, K. Marx e F. Engels frisavam exemplarmente os limites dos sentimentos puramente utópicos:

À medida que a luta de classes se acentua e toma formas mais definidas, o fantástico afã de abstrair-se dela, essa fantástica oposição que se lhe faz, perde qualquer valor prático, qualquer 
justificação prática. Eis porque, se, em muitos aspectos, os fundadores desses sistemas eram revolucionários, as seitas formadas por seus discípulos são sempre reacionárias, pois se aferram às velhas concepções de seus mestres apesar do ulterior desenvolvimento do proletariado. Procuram, portanto, e nisto são consequientes, atenuar a luta de classes e conciliar os antagonismos. Continuam a sonhar com a realização experimental de suas Utopias sociais: estabelecimento de falanstérios isolados, criação de colônias do interior, fundação de uma pequena Icária (...) (MARX, K.e ENGELS, F., op.cit., p.51/52).

A crítica ácida às Utopias de matriz idealista e/ou doutrinária não significa uma negação in totum da Utopia, mas exige a superação científica (materialista) das fantasias da sociedade futura. Não se trata de uma composição entre a Utopia e a ciência, ou pior, de uma cientifização das projeções do futuro. Os argumentos de Marx e Engels reclamavam, na verdade, a incorporação da prática social como elemento decisivo da construção do devir.

Henri Maller (Congédier l'Utopie) reclama um conceito de Utopia na crítica marxista das Utopias. Essa ausência teórico-conceitual teria conduzido as críticas de Marx a circunscreverem-se ao sentido vulgar da Utopia e, no seu limite, ao tratamento das Utopias como expressões ideológicas. É bem verdade que nas obras de Marx não são encontradas elaborações diretas e conclusivas a respeito do conceito de Utopia, porém a falta de um rigor teórico, ou de um modelo acabado, não significa uma despreocupação com o tema. Na Ideologia Alemã, a Utopia é interpretada sob a determinação de uma figuração idealista, considerada incapaz de reconhecer a atividade humana sensível e orientar a prática social efetivamente transformadora.

Trata-se, portanto, de uma crítica aberta às concepções liberais e pequeno-burguesas de projeção do futuro, como também às correntes socialistas que não aprenderam a andar sobre o solo da história real. A crítica às Utopias se confunde com crítica da ideologia burguesa e do ufanismo idealista do movimento socialista contidas nas obras de Claude-Henri de Saint Simon ( $O$ sistema Industrial), Charles Fourier (Tratado da Asśsociação Agrícola Doméstica), Robert Owen (Comunicado ao Condado de New Lanark) e Etienne Cabet (Viagem a Icária). F. Engels afirmaria, inclusive, numa passagem do livro Socialismo Utópico e Socialismo Científico, que as projeções utópicas tomavam o sentido de uma verdade absoluta independente do tempo, do espaço e do próprio desenvolvimento da história humana.

As Utopias idealistas carregavam a marca de argumentações criadas de "fora" das condições socioeconômicas e, por isso, incapazes de assumir uma forma diretamente prática. Nesse sentido, as Utopias não significavam nada além de um simples acaso de data e lugar, destituídas de qualquer valor prático.

$\mathrm{Na}$ análise do papel da crítica às Utopias nas obras de Marx e Engels, acentuamse as exigências de compromisso prático das Utopias com as recusas e promessas apresentadas na sua construção discursiva de antecipações do futuro. A partir daí são demarcados critérios para o seu real significado histórico e o entendimento de suas diferenças em relação às projeções doutrinárias e voluntaristas do devir. É assim que 
os autores do Manifesto Comunista recusam o sentido genérico de Utopia, estabelecendo um viés de análise de suas formas através do conceito de impossibilidade. Esse itinerário de reflexão coloca em causa a distinção entre a impossibilidade absoluta e a impossibilidade relativa do conteúdo utópico, desenhando uma linha de leitura e interpretação materialista das Utopias. Para tanto foi preciso recorrer à idéia da antecipação que, nos escritos daqueles pensadores do movimento socialista, significava o atributo de pensar o real pela via de suas tendências, fazendo do virtual uma referência crítica do espaço-tempo da experiência humana. A antecipação ganha um novo significado, pois é definida como uma construção que emana das práticas sociais: uma consciência que emerge da história e se realiza como história dos homens concretos.

O virtual localizado no campo da práxis, definida em Marx como atividade real e transformadora do mundo, se torna o elemento balizador do sentido das Utopias. Portanto, a Utopia não se resumiria exclusivamente a uma prática teórica ou filosófica de descoberta do real sem data ou lugar. A Utopia supera a condição genérica das Utopias até então compreendidas como antecipações do futuro que vêem a si mesmas como a possibilidade de ruptura com o real, ou como um programa de ação que traça objetivos que a prática deve aplicar independentemente das condições históricas. F. Engels explicita tal concepção ao distinguir a Utopia em duas grandes vertentes: as Utopias concretas e as Utopias abstratas.

As Utopias concretas teriam sua referência maior no movimento histórico da realidade revelando, assim, as possibilidades das transformações sociais. Nelas, o possível é elevado à categoria do pensamento para leitura da realidade social, como método de desvelamento dos embates que recortam a impossibilidade absoluta e a impossibilidade relativa da transformação revolucionária do mundo.

O virtual emerge, das Utopias concretas, como categoria de iluminação do espaço-tempo como momento da prática humana. O devir é interpretado como uma construção aberta de realizações possíveis e impossíveis e, ao mesmo tempo, uma construção crítica do real existente, abrindo as comportas do imaginário social para a transformação radical do presente-real opressor. A Utopia ganha, portanto, o sentido de uma narrativa ficcional do espaço e do tempo que alude às perspectivas de emancipação humana no seio dos conflitos e contradições de uma sociedade historicamente determinada. A Utopia em Marx é a Weltanschaung que deseja a transformação do real presentificado em sua própria historicidade.

Em contrapartida, as Utopias abstratas respondem por uma construção imaginária do devir que se opõe à superação do presente-real, em questão na sua própria narrativa. Nas Utopias abstratas, o futuro é composto na ausência do presente, criando um hiato entre a imagem-do-desejo e a necessidade do porvir. Sua incapacidade de plasmar-se ao movimento do real traduziria suas limitações teóricas (e práticas) de tornar-se uma referência de positividade no campo das lutas sociais. Por outro lado, a presença do futuro nas Utopias abstratas se afigura como um recurso normativó e dogmático de construções de sociedades ideais. O modelo é tomado como o medi- 
ador do mundo como ele deve ser, como algo suficientemente poderoso para substituir os sujeitos sociais concretos e as condições históricas. Nas Utopias abstratas, o sonho do futuro e a ideologia percorrem, lado a lado, a mesma margem do rio.

Nos atrevemos a afirmar que é na história social do espaço que se define o sentido e se demarca o lugar da Utopia nas Utopias, pois é a partir das representações espaço-temporais que podemos interpretar a qualidade do futuro que se deseja construir como presente. A intenção utópica é, portanto, um momento de fundação radical do possível. Momento que não se realiza agindo somente como uma tendência da consciência humana, mas como uma compreensão crítica da realidade objetiva e da ação prática transformadora. O pensamento-ação utópico é aquele que se quer mediador da relação real-possível-impossível da história humana. Nos parece ser esse o legado de Marx e de Engels à reflexão a respeito da Utopia: a constituição de um método de leitura e interpretação crítica das Utopias. Essa via aberta pela crítica utópica das Utopias em Marx e Engels nos permite um reencontro com o pensamento de Morus e, a partir daí, retomar as contribuições da narrativa de antecipação no movimento das relações humanas como espaço-tempo, principalmente em relação à cidade como Obra de Arte.

\section{A Utopia como Representação da Cidade}

O filósofo alemão Immanuel Kant definia as Utopias como um ideal regulador que apesar de alimentar o debate político, não possuía a menor possibilidade de realização humana. Podemos concordar com tal assertiva se nos detivermos, como Kant, na construção da Cidade-Estado ideal preconizada por Platão na República e nas Leis. Entretanto, ao incluirmos a obra de Morus ao debate, certamente abriremos novos horizontes para pensar o sentido das Utopias.

Em primeiro lugar, na Ilha de Morus, o Bem não significa uma essência distinta da existência, própria do Topos Naetos platônico. Na República de Platão o paradeigma habita o céu das essências, é estável e imutável, não existindo como qualidade da experiência sensível. Na Utopia de Morus, o Bem só pode ser compreendido a partir da existência. A essência do Bem é posta no plano da argumentação e da vida prática da construção humana. Desse modo, a Utopia não trata de uma educação dos corpos (dos homens, da cidade) a partir dos movimentos da Alma ou de essências reclusas num mundo inacessível aos não-filósofos. Em Morus, não encontramos um projeto de caráter político-pedagógico como na República de Platão, pois sua linha argumentativa envolve a criação de um modelo de sociedade que não é cópia de uma outra estrutura paradigmática que lhe é superior e que se busca imitar; a Utopia é o próprio modelo da Utopia. Rafael Hitlodeu nos permite encontrar a identidade da Ilha na diferença em relação à República Platônica, ao afirmar aos seus interlocutores: 
(...) mas, se tivesse estado comigo em Utopia (...), então não teria dificuldade de reconhecer que em nenhuma parte viu povo tão bem governado como lá (MORUS, 1997: p.51).

O futuro como retorno ao passado também era fio condutor do "programa platônico" para a cidade perfeita. É nesse sentido que o filosófo grego recorre a uma Atenas mítica, onde a harmonia e a felicidade vigoraram, como oposição à Atlântida, cidade considerada como a expressão da injustiça, das paixões desmedidas, das ambições, da degeneração, em resumo, do Excesso. Na Utopia de Morus, o futuro não representa um retorno ao passado mítico ou um contra-projeto nostálgico do presente, mas a construção de um espaço-tempo sob o impulso de novas e radicais relações humanas. A Utopia é um espaço habitado, cujas exigências do dever-ser incluem a superação de contradições reais e concretas. Rafael Hitlodeu assim enfatizava as condições históricas de sua república terrestre:

Agora, caro Morus, vou revelar-vos o fundo de minha alma, e dizer-vos os meus pensamentos mais íntimos. Em toda a parte onde a propriedade for um direito individual, onde todas as coisas se medirem por dinheiro, não se poderá jamais organizar nem a justiça nem a propriedade social, a menos que denomineis de justa a sociedade em que o que há de melhor é partilha dos piores, e que considereis perfeitamente feliz o Estado no qual a fortuna pública é presa de um punhado de indivíduos insaciáveis de prazeres, enquanto a massa é devorada pela miséria. (MORUS, ibidem, p.49)

A Utopia supera os limites das concepções idealistas do dever-ser, e aponta para os investimentos fundamentais para a transformação do presente-real:

Eis que invencivelmente me persuade que o único meio de distribuir os bens com igualdade $\mathrm{e}$ justiça, e de fazer a felicidade do gênero humano, é a abolição da propriedade. Enquanto o direito de propriedade for o fundamento do edifício social, a classe mais numerosa e mais estimável não terá por quinhão senão miséria, tormentos e desesperos (MORUS, ibidem, 50).

Morus afirmava que a sua Utopia apresentava-se como um êmulo da República platônica. Isto não significava reproduzir ou atualizar a obra do filósofo grego, mas, sobretudo, superar os limites da Atenas que lhe serve de modelo de perfeição e harmonia. O devir na Utopia significava um investimento de compreensão e ação no mundo sensível, tornando a prática social a instância fundante de sua possibilidade de realização. A opção pelo mundo sensível, à diferença da República de Platão, traça um vínculo da Utopia com a concretude da produção do espaço social, e reitera o vínculo entre o necessário e o possível no jogo de representações da criação do futuro como crítica do presente. Morus parece acompanhar a crítica de Aristóteles (A Política, Livro II) a respeito da República e das Leis, pois igualmente alerta para a exclusão política do indivíduo no modelo platônico de Cidade Justa. Não seria possível, dizia Aristóteles, fundar uma pólis justa e feliz com indivíduos infelizes e que não vivem como desejam. 
Na Utopia, o paradeigma não substitui a vida pulsante em nome da construção de uma comunidade harmoniosa. É a vida em sociedade que se coloca, como princípio da diversidade, no movimento de construção da forma da existência. Morus "confessa" seu estranhamento diante de uma sociedade que constrói seu modo de vida ao avesso da ordem modelar estabelecida:

\begin{abstract}
Assim que Rafael terminou sua narrativa, veio-me à mente uma quantidade de coisas que me pareceram absurdas nas leis e costumes Utopianos, tais como seu sistema de fazer a guerra, o culto, a religião e várias outras instituições. $\mathrm{O}$ que, sobretudo, transtornava as minhas idéias era o alicerce sobre o qual foi erguida esta estranha república, quero dizer, a comunidade de vida e de bens, sem tráfico de dinheiro. Ora, esta comunidade destrói radicalmente toda a nobreza e magnificência, todo o esplendor e majestade - coisas que, aos olhos da opinião pública, fazem a honra e o verdadeiro ornamento de um Estado (MORUS, 1997).
\end{abstract}

Em Platão e em Morus observamos a definição de formas de argumentação distintas em relação ao devir de uma sociedade que se quer justa e feliz. Enquanto Platão elabora a possibilidade de edificar um topos a partir de ideais reguladores e que transcendiam o mundo sensível, Morus faz suas apostas no topos da imanência, e coloca na emancipação das condições históricas o princípio adverso ao dever-ser. Abre-se, então, a possibilidade de leitura da escrita utópica em dois campos distintos e em duelo permanente. A primeira, de matriz platônica, inscreve. o futuro como distinção do presente, mas esgota esse mesmo futuro em um modelo fechado e linear da perfeição humana, priorizando o cessar do movimento e enredando o devir em um eterno presente cuja regulação é pré-determinada. Na segunda, a Utopia está empenhada na criação de representações do futuro como um momento do possível, repleto de lacunas a serem preenchidas permanentemente como a superação humana dos conflitos e contradições na radicalidade das imperfeições do presente. As duas vertentes celebram encontros entre o necessário e o contingente, entre possível e o impossível e, entre a regulação e a emancipação. Todos esses encontros ganham um espaço particular de manifestação: a cidade

É indispensável observar que a Utopia de Morus se inscreve no período do Renascimento Filosófico e Cultural, onde é celebrado o advento do Humanitas que proclama o homem como sujeito autônomo da história e o eleva à condição de primado da criação artística e filosófica. Morus faz da sua obra uma assinalação de rupturas localizadas nas primeiras décadas do século XVI, período em que desaba o mundo gótico e feudal diante do avanço do humanismo, das primeiras formas livres do capital (o capital dinheiro e o capital comercial) e da expansão geográfica do ecúmeno terrestre oferecida pela expansão comercial marítima. A Utopia se define, portanto, como uma narrativa cujo emblema é o homem como sujeito do espaço por ele (e para ele) construído, superando a cisão platônica entre o pensamento e a ação.

A Utopia de Morus é, sobretudo, o produto de um momento histórico de ruptura entre a imaginação-mimese, que estava ligada à idéia de tempo cíclico, e a imaginação criadora, que supõe um tempo aberto, como asseverou $\mathrm{H}$. Védrine (Les grandes 
conceptions de l'imaginaire, p. 44/45). Contudo, a Utopia tem sua verve criativa alimentada com as tradições do platonismo (a Justiça como ideal do Bem), do epicurismo (a busca do prazer) e do estoicismo (o espírito de comunidade natural dos homens), realizando, como indica Lacroix, a sua vocação filosófica de traçar a unidade entre a imaginação da mimeses e a imaginação da práxis. A Utopia define e abre um campo para as Utopias como um gênero cognitivo particular, cuja exigência primeva é pensar o ser no seio da existência, como atributo ontológico de afirmação de um outro devir humano. É nesse sentido que a Cidade das Almas de Platão é reconstruída como a Cidade dos Homens em Morus.

Não é demais relembrar, como faz Lewis Mumford (A Cidade na História), que é no Renascimento que se inaugura uma verdadeira revolução copernicana no sentido da cidade. É nesse período que a cidade é interpretada como espaço do Humano ideal e, por isso, concebida como Obra de arte. Multiplicam-se as cidades ideais nos tableaux de Alberti (De re edificatoria, 1455), de Martini (Tratado da arquitetura e da arte militar, 1479), Cataneo (A Arquitetura,1570), Palladio (Os Quatro Livros da Arquitetura), entre outros, cuja ambição maior é construir um objeto estético à luz da razão humana. O urbanismo acede ao status de ciência, encontrando no more geométrico o instrumento mais eficaz de antropomorfização da cidade como espaço da Humanitas. Círculos, triângulos, retas e segmentos de retas são consagrados como instrumentos de realização da perfeição da cidade como Obra humana. $\mathrm{O}$ cálculo racional e a arte pública encontram-se na forma de praças, jardins, edifícios e monumentos. A paisagem é tomada como o lugar privilegiado da arte e da razão laicizada. Morus faz parte desse movimento que toma a cidade como um estatuto estéticocientífico, porém doará às cidades da Utopia significados mais abrangentes e mais generosos do que os apresentados pelos seus contemporâneos.

\section{A Cidade no devir histórico da Utopia}

A Utopia é uma Ilha imaginária cujos vizinhos são os alaopolites, cidadãos sem cidades e, os achorianos, homens sem país. Aqui o jogo de representações do espaço implica em assinalações dos não-Utopianos como seres desprovidos de suas condições de existência social plena: a cidade e o país. Metáforas que aludem às transformações do espaço social na Inglaterra do século XVI, sobretudo àquelas que impulsionavam o cercamento dos campos e a desterritorialização do campesinato. A compreensão analógica do vivido se faz acompanhar de uma construção metonímica que desloca para um lugar fictício - A Utopia - o direito dos homens à cidade e ao país. Portanto, a Utopia emerge como crítica do presente e possibilidade instituinte da (re)apropriação do espaço como condição de uma nova experiência humana. Morus convoca a necessária construção de uma comunidade política através da qual

todos tenham acesso aos benefícios e a riqueza seja indistintamente repartida de modo que cada um goze abundantemente de todas as comodidades da vida. (MORUS, op. cit, p. 49). 
Estamos diante de uma narrativa que elabora a negação de uma sociedade dada historicamente e, simultaneamente, projeta a positividade de uma outra radicalmente diferente.

A Utopia de Morus tem a marca do tempo-espaço de sua construção e as sementes já lançadas do Porvir. Esse encontro entre a essência e a existência, entre o ser e o devir, entre a mimesis e a práxis e, sobretudo, entre o real e a fiç̧ão constituirá o cerne da tradição narrativa das Utopias concretas como representação do espaço social. A Utopia se inscreve como uma narrativa estética que se apóia na elaboração de imagens para estabelecer os princípios éticos das relações humanas. Contudo, na qualidade de discurso ficcional, apresenta-se como um conjunto de imagens de um outro lugar; uma paisagem no espelho reveladora do mundo a partir de seus contrários, assumindo a condição de mediação crítica do movimento da história. Para tanto, Morus lança mão da ficção para retraduzir, na escrita utópica, o espaço do devir, e, a partir dele, estabelecer um corte ontológico com a realidade existente. Morus repõe, no plano da representação ficcional, a transformação do sentido da cidade antiga e medieval que se organizava em torno das Almas, dos Deuses e dos Mitos, para uma cidade como produção humana, como forma-conteúdo da própria consciência humana. A projeção ficcional da Utopia é uma busca de revelação do ethos da criação humana através da representação da cidade como prattein.

A intenção utópica de Morus nos conduz a Amaurota - a Cidade Miragem - uma paisagem visível e invisível, decifrável e misteriosa. A cidade-capital da Utopia repousa às margens do Anidra (um rio sem água), localizando-se em lugar nenhum para estar presente em qualquer lugar da vida social concreta. Conhecê-la é, para Morus, conhecer todas as demais cidades da Utopia (e do mundo que lhe é contrapontístico). Desse modo, a Ilha é construída a partir da cidade, ou melhor, a partir de cinqüenta e quatro cidades espaçosas e magníficas - cujos hábitos, costumes, instituições e leis são perfeitamente idênticas. É a cidade que dá vida e sentido de essência, através da existência, à Utopia.

É a presença das cidades que elege a Utopia como espaço da civilização humana e, como afirma a personagem Rafael Hitlodeus, a melhor e superior representação de uma verdadeira República. A presença da cidade na narrativa ficcional da Utopia requer, como plausibilidade da antecipação visada, a composição de uma paisagem geográfica para lhe atribuir um sentido de existência:

Amaurota se estende em doce declive sobre a vertente de uma colina. Sua forma é de quase um quadrado. Começa a estender-se um pouco acima do cume da colina, prolonga-se cerca de dois mil passos sobre as margem do rio Anidra, alargando-se à medida que vai margeando o rio ( MORUS, op. cit., p. 61)

A paisagem da cidade é apresentada nos seus detalhes e, deles, brotam situações de uma organização espacial que prima pela simetria e pela beleza: 
As ruas e as praças são convenientemente dispostas, seja para o transporte, seja para abrigarse do vento. Os edifícios são construídos confortavelmente; brilham de elegância e de conforto e formam duas fileiras contíguas, acompanhando de longo as ruas, cuja largura é de vinte pés (MORUS, idem, p. 62).

A técnica e a arte são instrumentos que potencializam a criação da paisagem, porém a qualidade da cidade é apreciada na participação dos habitantes na sua transformação criativa:

(...) no começo, as casas eram muito baixas, não havia senão choupanas, cabanas de madeira, com paredes de barro e tetos de palha, terminados em pontas. As casas hoje, são elegantes edifícios de três andares, com paredes externas de pedra ou tijolo e paredes internas de estuque. Os tetos são chatos, recobertos de uma matéria moída e incombustível, que não custa nada e protege mẹlhor que o chumbo dos danos do tempo (MORUS, ibidem, p. 63).

E. Bloch (Princípio da Esperança) afirmava que toda ventana utópica requer uma paisagem que celebre a geografia da matéria terrestre dos sonhos. É através da paisagem que se recorta uma nova forma-conteúdo da sociedade outra:

Atrás, e entre as casas, abrem-se vastos jardins. Em cada casa há uma porta que dá para a rua e outra para o jardim. Estas duas portas se abrem facilmente com um ligeiro toque, e deixam entrar o primeiro que chega.

(...) Os habitantes da Utopia aplicam aqui um princípio da posse comum. Para abolir a idéia da propriedade individual e absoluta, trocam de casa todos os dez anos e tiram a sorte de que thes deve caber na partilha ( MORUS, ibidem, p. 62).

Na Utopia, a paisagem é um portal onde a negação do presente e os sonhos do futuro tecem seus encontros. Todavia, a ficção utópica do espaço precisa transparecer como uma construção da razão, força capaz de livrar a cidade (e seus habitantes) das vicissitudes, das incertezas e das atribulações do império das necessidades. É assim que, na Utopia de Morus, a produção do espaço é revestida pelo imaginário que estabelece um devir de relações mútuas entre os cidadãos. A Utopia convida os homens a superação do reino das necessidades, proclamando o valor de uso como virtude social:

(...) no centro de cada quarteirão há uma praça, onde se juntam todos os objetos (...), os produtos do trabalho de cada família; ali, cada pai de família busca o que precisa para si e os seus e, sem dar dinheiro ou qualquer outra contrapartida, recebe o que foi buscar (MORUS, 1997).

Residências, jardins, praças, edifícios públicos, mercados, hospitais, restaurantes (...) estão dispostos num jogo de distanciamentos e aproximações capazes de reproduzir as condições de conforto, segurança e atendimento das necessidades do indivíduo e da comunidade. É obedecendo a estas finalidades que as cinqüenta e quatro 
cidades são edificadas sobre o mesmo plano, possuindo os mesmos estabelecimentos e edifícios públicos, modificados segundo as exigências das localidades. A unidade é concebida no quadro das particularidades, reforçando relações solidárias entre cidades e cidadãos:

As primeiras sessões do senado são consagradas a levantar a estatística econômica das diversas partes da Ilha. Desde que se verificam os pontos onde há demais e os pontos onde não há o bastante, o equilíbrio é restabelecido enchendo-se a carência das cidades infelizes com a superabundância das cidades mais favorecidas. Esta compensação é gratuita. A cidade que dá nada recebe em troca da parte que entrega; e, reciprocamente, recebe de graça de uma outra cidade à qual nada deu (MORUS, 1997: p. 80).

É verdade que a ficção do espaço n'A Utopia ganha um ordenamento racional e objetivo, porém Morus não é um geômetra por excelência (ou vocação ditatorial). Suas medidas são a expressão de mediações necessárias ao discurso imagético que, por sua vez, faz da ficção uma projeção concreta (porque é crítica) do espaço das possibilidades de uma cidade constituída à luz da razão humana. Aqui reside um ponto nodal da crítica às utopias: o confronto entre "paraísos geométricos" e "infernos terrestres" (MUMFORD, 1982).

É comum encontrarmos nos críticos anti-utópicos a ênfase nos aspectos geométricos da produção da cidade como representação da cidade ideal. Maitê Clavel (Des Villes en Utopie) alude às formas regulares que desenham espaços funcionais (a exemplo da Icária de Cabet e dos Falanstérios de Fourier) representativos dos esquemas imaginados pelo gênero utópico. Wunenburger (L'Utopie ou la crise de l'imaginaire) condena a matematização da vida como uma retórica comum ao pensamento dos utopistas. Outros, como Cioran (História da Utopia), fazem coro às denúncias a respeito da obsessão uniformizadora das Utopias e, não raramente, sugerem uma ingenuidade profunda nos sistemas aritméticos preconizados para as cidades ideais (PAPAGEORGIOU, 1977).

Contudo, Morus não pode ser interpretado como matriz de paraísos dirigidos. Utopos, criador do plano geral das cidades, não conclui as construções e embelezamentos, sendo sábio o suficiente para entregar às gerações futuras o trabalho de continuidade e aperfeiçoamento de sua obra (MORUS, 1997: p. 63). A cidade da Utopia não é edificada como uma projeção espacial de uma ordem política e econômica a serviço de uma autoridade laica ou religiosa, ou de construções ordenadas que reificam a vida humana através de círculos, triângulos e quadrados. $\mathrm{Na}$ Utopia o recurso à simetria - alinhamentos de ruas e residências, uniformidade das construções, localização de objetos espaciais segundo intervalos regulares, investimentos funcionais para a circulação de pessoas e bens - é uma forma de expressão de uma realidade tomada na sua complexidade, tendo como propósito maior revelar as possibilidades da razão humana para superar problemas concretos da sociedade, pois, como afirma Bazco: 
As representações de uma cidade outra e feliz revelam uma maneira específica de imaginar o social: as Utopias são lugares privilegiados onde se exerce a imaginação, onde são acolhidos, trabalhados e produzidos os sonhos individuais e coletivos (BAZCO, 1978: p. 31).

O devir terrestre da Cidade, sua produção e organização, significa a descrição do próprio homem e de suas qualidades éticas. Morus parece acompanhar as postulações de Aristóteles, quando este afirma ser o sentido e a finalidade da pólis a realização plena da vida de sujeitos (individuais e coletivos) autônomos e ativos.

Por outro lado, a forma construída sob princípios estético-racionais não é apanágio de reprodução de relações excludentes de dispositivos disciplinares de poder, mas recurso e abrigo de um novo ethos de relações sociais, que se traduz como o entendimento de deveres e compromissos simétricos entre os cidadãos. À forma da cidade é atribuído um papel especial, pois será através dela que as representações ganham um atributo ético novo, capaz de valorizar as ações humanas como potência de construção do mundo, ou seja, a exposição da comunidade política capaz de instituir critérios de avaliação das qualidades dos valores, juízos, hábitos e princípios de uma sociedade que se quer justa:

O fim das instituições sociais na Utopia é de prover antes de tudo às necessidades do consumo público e individual: e deixar a cada um maior tempo possível para libertar-se da servidão do corpo, cultivar livremente o espírito, desenvolvendo suas faculdades intelectuais e pelo estudo das ciências e das letras. É nesse desenvolvimento completo que eles põem a verdadeira felicidade (MORUS, 1997: p.71).

À Cidade da Utopia corresponde, então, uma atividade humana carregada de intencionalidades objetivas e subjetivas como expressão das relações prático-sensíveis entre sujeitos históricos. É sob esse prisma que a relação identidade e diferença define o estilo de viver feliz na Cidade e é, ao mesmo tempo, o fundamento de toda emancipação humana. Na Utopia de Morus, a forma e o estilo se combinam, na medida que confessam a dimensão mais recôndita do Ser em movimento e sua realização como valor e ação social. A cidade utópica emerge como crítica da sociedade real, representando o ethos de uma realidade outra, de uma outra lógica social e de outras relações dos homens entre si:

Eis o que leva os Utopianos a afirmarem que uma vida honestamente agradável quer dizer que a volúpia é o fim de todas as nossas ações; que tal é a vontade da natureza e que obedecer a esta vontade é ser virtuoso.

A natureza, dizem eles, convida todos os homens a se ajudarem mutuamente e a partilharem em comum do alegre festim da vida. Esse conceito é justo e razoável, pois não há indivíduo tão altamente colocado acima do gênero humano que somente a Providência deva cuidar dele (...). É por isso que os Utopianos pensam que é necessário observar não só as convenções privadas entre simples cidadãos, mas ainda as leis públicas, que regulam a distribuição das comodida- 
des da vida, em outros termos, que distribuem a matéria do prazer, quando estas leis foram justamente promulgadas por um bom príncipe, ou sancionadas pelo consentimento geral do povo, nem oprimido pela tirania, nem embuído pelo artíficio.

A sabedoria reside em procurar a felicidade sem violar as leis. E a religião é trabalhar pelo bem geral. Calcar aos pés a felicidade de outrem, em busca da sua, é uma ação injusta. (MORUS, 1997: p. 87/88)

A Cidade é, então, concebida como Obra, não em função do seu conteúdo artístico, mas pela totalidade social que pretende abarcar em seu movimento de construção. É nesse sentido que podemos afirmar que Utopia projeta uma ética a partir do espaço ficcional da cidade, pois é na cidade utópica que as virtudes individuais e coletivas ganham momento e lugar. Morus nos faz crer que a intenção ética da Utopia é a criação do sujeito estético:

o povo Utopiano é espiritual, amável, engenhoso, ama o lazer, é paciente no trabalho, quando o trabalho é necessário; sua paixão favorita é o exercício do espírito (MORUS, 1997).

Assim, o devir do sujeito estético significa um programa utópico que define a cidade como espaço social de homens e mulheres livres, autônomos e coletivos. A cidade é esse espaço ético-estético concreto, representando a complẻxa tessitura de ações, memórias, histórias, lutas, dramas e sonhos humanos. O sujeito estético de Morus reclama, nas representações da cidade, a construção de novas práticas sociais que alarguem o horizonte do vivido. A cidade como (re)criação do espaço da liberdade é a Utopia da Utopia.

\section{A CIDADE DO DEVIR NA UTOPIA DE THOMAS MORUS}

Resumo: Cidade e Utopia são temas que se cruzam na literatura e na filosofia, alimentando o ideário de uma sociedade nova. A Utopia, de Thomas Morus, e A República, de Platão, fazem a referência dessa literatura e desse tema na filosofia e no pensamento social.

Palavras-chaves: Cidade, Utopia, Sociedade do Futuro

\section{THE FUTURE CITY IN THOMAS MORUS UTOPIA}

Abstract: City and utopia are crossed themes both in literature and philosophy, feeding an idealism of a new society. Thomas Morus Utopia and Plato's Republic are references of that literature and that theme on philosophy and social thought.

Key words: City; Utopia; Future Society

\section{BIBLIOGRAFIA}

ARISTÓTELES. 1991. A Política. São Paulo: Martins Fontes

BASCO, L. 1978. Lumières de Utopie. Paris: Payot.

BLOCH. E. 1982. Le Principe Espèrance. Paris: Gallimard. 
des da vida, em outros termos, que distribuem a matéria do prazer, quando estas leis foram justamente promulgadas por um bom príncipe, ou sancionadas pelo consentimento geral do povo, nem oprimido pela tirania, nem embuído pelo artíficio.

A sabedoria reside em procurar a felicidade sem violar as leis. E a religião é trabalhar pelo bem geral. Calcar aos pés a felicidade de outrem, em busca da sua, é uma ação injusta. (MORUS, 1997: p. 87/88)

A Cidade é, então, concebida como Obra, não em função do seu conteúdo artístico, mas pela totalidade social que pretende abarcar em seu movimento de construção. É nesse sentido que podemos afirmar que Utopia projeta uma ética a partir do espaço ficcional da cidade, pois é na cidade utópica que as virtudes individuais e coletivas ganham momento e lugar. Morus nos faz crer que a intenção ética da Utopia é a criação do sujeito estético:

o povo Utopiano é espiritual, amável, engenhoso, ama o lazer, é paciente no trabalho, quando o trabalho é necessário; sua paixão favorita é o exercício do espírito (MORUS, 1997).

Assim, o devir do sujeito estético significa um programa utópico que define a cidade como espaço social de homens e mulheres livres, autônomos e coletivos. A cidade é esse espaço ético-estético concreto, representando a compléxa tessitura de ações, memórias, histórias, lutas, dramas e sonhos humanos. O sujeito estético de Morus reclama, nas representações da cidade, a construção de novas práticas sociais que alarguem o horizonte do vivido. A cidade como (re)criação do espaço da liberdade é a Utopia da Utopia.

\section{A CIDADE DO DEVIR NA UTOPIA DE THOMAS MORUS}

Resumo: Cidade e Utopia são temas que se cruzam na literatura e na filosofia, alimentando o ideário de uma sociedade nova. A Utopia, de Thomas Morus, e A República, de Platão, fazem a referência dessa literatura e desse tema na filosofia e no pensamento social.

Palavras-chaves: Cidade, Utopia, Sociedade do Futuro

\section{THE FUTURE CITY IN THOMAS MORUS UTOPIA}

Abstract: City and utopia are crossed themes both in literature and philosophy, feeding an idealism of a new society. Thomas Morus Utopia and Plato's Republic are references of that literature and that theme on philosophy and social thought.

Key words: City; Utopia; Future Society

\section{BIBLIOGRAFIA}

ARISTÓTELES. 1991. A Política. São Paulo: Martins Fontes

BASCO, L. 1978. Lumières de Utopie. Paris: Payot.

BLOCH. E. 1982. Le Principe Espèrance. Paris: Gallimard. 
CIORAN, E. M. 1994. História e Utopia. Rio de Janeiro, Rocco.

CHOAY, F. 1979. O urbanismo, Utopias e realidades. São Paulo: Perspectiva.

CLAVAL, Paul. 1999. A Geografia Cultural. Florianópolis: EUFSC.

CLAVEL, Maïté. 1992. Des espaces en utopie. Géographie et Cultures, nº 3, p.4556.

ENGELS, F. 1989. Socialismo Utópico e Socialismo Científico. São Paulo: Ed. Moraes.

LACROIX, J. 1996. A Utopia. Rio de Janeiro: J. Zahar.

MALLER, H. 1995. Convoiter L'Impossible. L'utopie avec Marx, malgré Marx. Paris: Albin Michel. L'Harmattan.

1994. Congedier L’Utopie? - L'utopie selon Karl Marx. Paris:

MARIN, L. 1973. Utopiques: Jeux d'espaces. Paris: Minuit.

MARX, K. 1974. Manuscritos Econômico-Filosóficos. São Paulo: Abril Cultural. . e ENGELS F. 1985. O Manifesto do Partido Comunista. São Paulo: Nova Stella.

MORUS, Thomas. 1997. A Utopia. São Paulo: Nova Cultural.

MUNFORD, L. 1982. A Cidade na História. Martins Fontes: São Paulo

PAPAGIORGIOU, G. J. 1977. Fundamental problems of the theoretical planning. Environment and Planning. A,9, p.1329-1356.

PAQUOT, T. 1999. A Utopia: Ensaio acerca do real. Rio de Janeiro: DIFEL.

PLATÃO. 1966. A República (Diálogos v.III). Rio de Janeiro: Ediouro

RUYER, R. 1988. L'Utopie et les utopies. Paris: G. Montfort.

SZACHI, J. 1972. As Utopias. Rio de Janeiro Paz e Terra.

VÉDRINE, H. 1990. Les grandes conceptions de l'imaginaire. Paris: Le Livre de poche.

WUNENBERGER, J- J. 1979 . L' Utopie e la crise del'imaginaire. Paris: Delarger 